\title{
Service Quality Effects on Customer Satisfaction in Banking Industry
}

\author{
Tran Van Quyet ${ }^{1}$, Nguyen Quang Vinh ${ }^{2}$ and Taikoo Chang $^{3}$ \\ ${ }^{1}$ Thai Nguyen University of Economic and Business Administration, Tan Thinh \\ Ward, Thai Nguyen City, Vietnam \\ quyettv@yahoo.com \\ ${ }^{2}$ Dai Nam University, 56 Vu Trong Phung St. Thanh Xuan, Hanoi, Vietnam \\ Quangvinh191081@gmail.com \\ ${ }^{3}$ Dept of Economics, Daegu University, 201 Daegudaero, Chinryangup, \\ Kyungsansi, Kyungbuk, 712-714, Rep. of Korea \\ Corresponding Author: tkchangl@hanmail.net
}

\begin{abstract}
This study contributes to the literature by considering a model for testing the quality of deposit services in the banking industry. The results indicating support for the hypotheses suggest that the five SERQUAL factors can be used to test banking services based on the whole system. Previous studies have shown that satisfying customers is not enough to retain them because even satisfied customers may defect at a high rate in many industries. Vietnam is a developing economy, and its banking sector has wide geographic reach catering to needs of a diverse range of customers. In this regard, the Vietnamese context offers a good opportunity for examining the issue of banking quality. Most customers have difficulty in understanding the complex nature of financial products and thus tend to focus on brand names, which are generally built on quality services.
\end{abstract}

Keywords: Banking Industry, Deposit Service, Vietnamese Commercial Bank, SERVQUAL Model, Customer Satisfaction

\section{Introduction}

Banks require customers to survive and grow. In this context, deposit services have undergone changes across the world as a result of economic deregulation, government policies, globalization, information and communication technology. One important outcome of such changes has been the intensification of competition in the financial services industry. To remain competitive, financial institutions have provided an increasingly diverse range of financial services (Hinson, et al., 2006). Here the key to success is to remain competitive and constantly improve the quality of services to better meet customers' needs, and the key to providing superior services is to clearly understand and appropriately respond to customers' expectations because customers compare perceptions with expectations in judging the quality of a firm's service offerings. The banking industry provides short-term as well as long-term funds for deposit services. Banks provide liquidity on demand to depositors through the current account and extend credit as well as liquidity to borrowers through lines of credit (Kashyap, et al., 1999).

Marketing theory has identified the core factors influencing customer satisfaction, particularly in the service sector, but few studies have considered the Vietnamese context. This raises the question of what key factors in the SERVQUAL model influence customer satisfaction with deposit services in Vietnam's banking industry. 


\section{A Literature Review}

Samli and Frohlich (1992) showed that delivering quality services to customers is a must for success and survival in today's competitive banking environment. Tsoukatos and Mastrojianni (2010) examined the determinants of quality retail banking services to build a quality scale and used BSQ in banks to better understand the determinants of quality in the industry. They employed a two-stage process of a literature review and an empirical analysis of retail banking and analyzed data through a reliability test, a factor analysis, and a regression analysis to determine the composition and evaluate its reliability and value. They showed the determinants of quality retail banking services to include assurance/empathy, efficiency, reliability, and confidence, reflecting a combination of SERVQUAL and BSQ scales. Among others, the provision of high-quality services increases the rate of customer retention, helps to attract new customers through word-ofmouth communication, increases productivity, expands the market share, reduces staff turnover and operating costs, and improves employee morale, financial performance, and profitability (Hinson, et al., 2006). They focused mainly on bank and customer factors and close relationships based on the service quality of banks satisfying customers.

The quality of banking services in Canada and Tunisia was examined to compare customers' perception of the quality of banking services in Tunisia and Canada. For this, they constructed a scale of service quality satisfaction and customer loyalty and collected data through a questionnaire from two convenience samples of bank customers ( $\mathrm{n} 1=\mathrm{n} 2=$ 250 in Canada and 222 in Tunisia). They measured service quality by using the SERVQUAL scale factors (tangibility, reliability, responsiveness, assurance, and empathy) and analyzed data through a confirmatory factor analysis, an ANOVA, and a linear regression analysis. They found that Canadians perceived higher service quality than Tunisians. For Canadians, empathy and reliability were the most important factors reducing the relative importance of customer satisfaction and loyalty, whereas for Tunisians, these factors were reliability and responsiveness.

Lymperopoulos and Chaniotakis (2006) examined the role of service quality in the selection of banks for deposit services to provide a deeper understanding of customers' purchase behaviors in the bank selection process and offer bank managers some useful insights into the development of high-quality customer relationships. They reviewed the literature on bank selection criteria, field studies, the identification of factors influencing the choice of customers, and the development of management-related impacts and conducted a survey of 1,092 bank customers in Athens. They identified factors as the core selection criteria for the choice of consumer banking. In addition, they found the quality of banking services as the most important factor considered by customers who are evaluating the provider of their mortgage and attempting to establish long-term relationships. Three other factors were product attributes, access, and communication.

Herington, et al. (2007) explored the effects of quality online services on the level of customer interest and the development of customer relationships. They conducted a survey of 200 Australian users of online banking services to collect data and employed a factor analysis and a linear structural model to test the model. They found the quality of online services not affecting the interest of clients and the trust in or development of strong relationships with customers to be related to loyalty. However, the efficiency of quality online services was related to trust and had an indirect effect on customer relationships through trust. Personal needs, the organization's website, and the quality of online services were related to loyalty, and here personal needs had the greatest impact.

Pikkarainen, et al. (2006) used the EUCS (end-user computing satisfaction) model to investigate the satisfaction of users of online banking services. The conducted a survey ( $\mathrm{n}$ $=268$ ) through convenient sampling. After analysis, they conducted a confirmatory factor analysis with LISREL 8.7 to test models of online banking services, and their analysis results provide three components (content, ease of use, and accuracy) from the original model. 
In sum, the theme "quality of service" has become an increasingly important topic because of its close relationship with factors influencing the cost of production (Crosby, 1979), customer satisfaction (Bolton, et al., 1991), customer loyalty (Reichheld \& Sasser, 1990), and positive word-of-mouth behaviors of customers. In addition, in financial and banking services, particularly deposit services, Vietnamese banks have strengthened and improved the quality of their services to compete more effectively and thus facilitate their foundation and sustainable development to meet these requirements, which are urgently required in the process of regional integration and the world. Further, individual banks may require specific studies to consider the cross-transparency of their service quality, which can define their most effective marketing strategies.

Based on the above discussion, Figure 1 proposes this study's research framework.

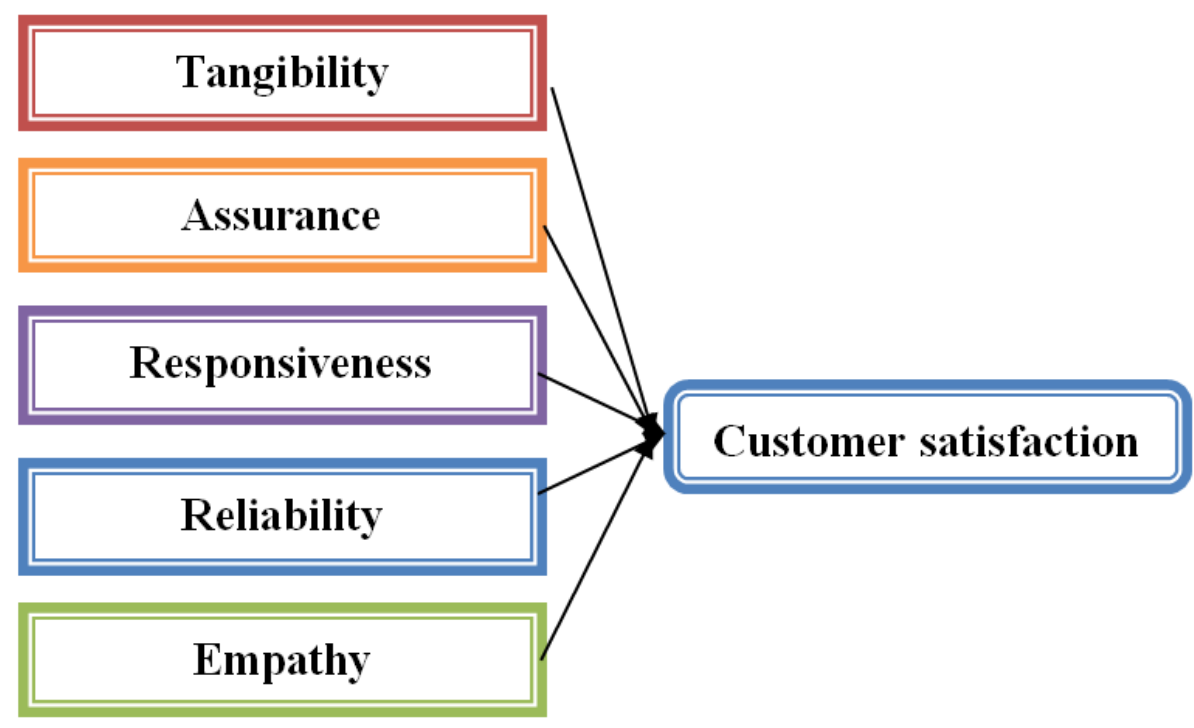

Figure 1. The Research Framework

Based on the theoretical discussion, Table 1 proposes this study's hypotheses.

Table 1. Research Hypotheses

\begin{tabular}{ll}
\hline Hypothesis & Description \\
\hline H1 & Tangibility has a significant effect on customer satisfaction. \\
H2 & Assurance has a significant effect on customer satisfaction. \\
H3 & Responsiveness has a significant effect on customer satisfaction. \\
H4 & Reliability has a significant effect on customer satisfaction. \\
H5 & Empathy has a significant effect on customer satisfaction. \\
H6 & Gender affects the level of satisfaction with deposit services of VCBs. \\
H7 & The level of experience affects the level of satisfaction with deposit \\
& services of VCBs. \\
H8 & Age affects the level of satisfaction with deposit services of VCBs. \\
\hline
\end{tabular}

\section{Methodology}

The SERVQUAL model was used to develop a questionnaire. The questionnaire had 22 items for 5 factors. The target population included current and former customers of deposit services of VCBs. According to Cooper and Schindler (2011), researchers use non-probability sampling to save money and time. In addition, they suggest that probability sampling does not always ensure accuracy and that ensuring it is not possible in some cases. In this study, the questionnaire was distributed to customers in Hanoi. 
Determining an appropriate sample size remains a controversial topic. MacCallum, Widaman, Zhang, and Hong (1999) summarized views of previous studies on minimum standards for sample size in a factor analysis by citing Gorsuch (1983), who suggested that a sample should be at least five times the number of variables. In the present study, the questionnaire had a total of 24 items, and therefore the minimum sample size was determined to be $120(24 \times 5=120)$.

\section{Results}

\subsection{The Respondent Profile}

As shown in Table 2, a total of 150 customers were considered. Among these, 88 $(58.7 \%)$ were female. There were fewer customers with some VCB experience in longtime accounts.

Table 2. The Respondent Profile

\begin{tabular}{lcc}
\hline Characteristic & Frequency & $\%$ \\
\hline Gender & 62 & \\
Male & 88 & 41.3 \\
Female & 150 & 58.7 \\
Total & & 100.0 \\
Age & 20 & \\
18-35 & 66 & 13.3 \\
$36-55$ & 64 & 44.0 \\
Over 55 & 150 & 42.7 \\
Total & & 100.0 \\
Experience & 47 & \\
Less than 1 year & 69 & 31.3 \\
1-5 years & 34 & 46.0 \\
More than 5 years & 150 & 22.7 \\
Total & & 100.0 \\
\hline
\end{tabular}

\subsection{Reliability}

The principle component method was used for an explorative factor analysis. Three main factors with 24 items were loaded into the system. The 21 items of SERVQUAL model were factorially analyzed. According to the results, the Kaiser-Meyer-Olkin value was .929 , and Bartlett's test of sphericity was significant at the .000 level. Table 3 reports the factor eigenvalues greater than or equal to 1.0 and variables with factor loadings greater than .5 .

Table 3. A Factor Analysis of the SERVQUAL Model

\begin{tabular}{|c|c|c|c|c|c|}
\hline \multirow{2}{*}{ Item } & \multicolumn{5}{|c|}{ Component } \\
\hline & Tangibility & Assurance & Responsiveness & Reliability & Empathy \\
\hline TA1 & .882 & & & & \\
\hline TA2 & .824 & & & & \\
\hline TA3 & .769 & & & & \\
\hline TA4 & .763 & & & & \\
\hline TA5 & .734 & & & & \\
\hline AS1 & & .790 & & & \\
\hline AS2 & & .775 & & & \\
\hline AS3 & & .671 & & & \\
\hline AS4 & & .637 & & & \\
\hline
\end{tabular}


AS5

RS1

RS2

RS3

RE1

RE2

RE3

EM1

EM2

EM3

Eigenvalue $\quad 6.138$

VE $(\%)^{*} \quad 32.308$

888
.602

.842

.709

.812

.710

.702

.727

.666

.590

1.009

5.309

.695

Total variance explained $=67.166, \mathrm{KMO}=.929, \mathrm{p}=.000$.

The factor analysis revealed five factors accounting for $67.166 \%$ of the total variance. SERVQUAL model factors were labeled as "tangibility" (32.308), "assurance" (12.502), "responsiveness" (9.622), "reliability" (7.427), and "empathy" (5.309). To test the reliability and internal consistency of each factor, its Cronbach's alpha was determined. According to the results, the alpha coefficients were .888 for tangible, .812 for assurance, .711 for responsiveness, .679 for reliability, and .695 for empathy.

In terms of customer satisfaction, three items were loaded. According to the results, $76.363 \%$ of the total variance was explained with an eigenvalue greater than 1.0, and the Kaiser-Meyer-Olkin value was .722. Bartlett's test of sphericity was significant at the .000 level. In terms of the reliability and internal consistency of factors, Cronbach's alpha was determined to be .845 (Table 4). Cronbach's $\alpha$ ranged from .888 to .679 , indicating that all factors were accepted and reliable.

Table 4. A Factor Analysis of Customer Satisfaction

\begin{tabular}{ccccccc}
\hline Item & $\begin{array}{l}\text { Factor } \\
\text { loading }\end{array}$ & Eigenvalue & $\begin{array}{l}\text { Total variance } \\
\text { explained }\end{array}$ & $\alpha$ & KMO & $\begin{array}{l}\text { P- } \\
\text { value }\end{array}$ \\
\hline SAT1 & .894 & & & & & \\
SAT2 & .872 & & & & & \\
SAT3 & .855 & 2.291 & 76.363 & .845 & .722 & .000 \\
\hline
\end{tabular}

\subsection{Results for Hypotheses}

According to the results, customer satisfaction with deposit services of banks depended on the following factors: Tangibility had the greatest effect $(\beta=0.717)$. Facilities and equipment also affected lending operations of banks, suggesting that banks that lag behind or are less developed are less likely to attract customers. Empathy ranked second ( $\beta=$ 0.486), suggesting that, to attract customers, banks should not only improve the quality of their utility services and products but also make greater use of a manual business culture such as customer relationship with bank employees. Assurance ranked third $(\beta=0.452)$, which may explain the request by the State Bank of Vietnam (SBV) for credit institutions and bank branches to strengthen the security and safety of their information technology systems. Responsiveness ranked fourth $(\beta=.340)$. This may be explained by the fact that account customers increasingly prefer attention related to the range of services and the timeliness of budgets. Reliability ranked last $(\beta=.228)$, suggesting that, to attract capital, banks rely heavily on client trust. The accuracy of this trust depends on the quality of information offered by the bank. In terms of respondent characteristics in their satisfaction with deposit services of VCBs, only the gender variable showed a difference in the level 
of satisfaction between male and female respondents. Service experience and age showed no differences in the level of satisfaction between respondents. These results suggest that female customers are more likely to be careful and require better services than their male counterparts.

Table 5. Results for Hypotheses

\begin{tabular}{|c|c|c|}
\hline Hypothesis & Description & Result \\
\hline $\mathrm{H} 1$ & $\begin{array}{l}\text { Tangibility has a significant effect on customer } \\
\text { satisfaction. }\end{array}$ & Supported \\
\hline $\mathrm{H} 2$ & $\begin{array}{l}\text { Assurance has a significant effect on customer } \\
\text { satisfaction. }\end{array}$ & Supported \\
\hline H3 & $\begin{array}{l}\text { Responsiveness has a significant effect on customer } \\
\text { satisfaction. }\end{array}$ & Supported \\
\hline $\mathrm{H} 4$ & $\begin{array}{l}\text { Reliability has a significant effect on customer } \\
\text { satisfaction. }\end{array}$ & $\begin{array}{l}\text { Partially } \\
\text { Supported }\end{array}$ \\
\hline H5 & $\begin{array}{l}\text { Empathy has a significant effect on customer } \\
\text { satisfaction. }\end{array}$ & Supported \\
\hline H6 & $\begin{array}{l}\text { Gender affects the level of satisfaction with deposit } \\
\text { services of VCBs. }\end{array}$ & Supported \\
\hline $\mathrm{H} 7$ & $\begin{array}{l}\text { The level of experience affects the level of } \\
\text { satisfaction with deposit services of VCBs. }\end{array}$ & $\begin{array}{l}\text { Not } \\
\text { supported }\end{array}$ \\
\hline H8 & $\begin{array}{l}\text { Age affects the level of satisfaction with deposit } \\
\text { services of VCBs. }\end{array}$ & $\begin{array}{l}\text { Not } \\
\text { supported }\end{array}$ \\
\hline
\end{tabular}

\section{Conclusions}

This study examines the relationships between the five factors in the SERVQUAL model and customer satisfaction with deposit services of VCBs. According to the results, all five factors were positively related to customer satisfaction. However, reliability had only partial support, indicating a need to improve reliability for VCBs wishing to be more competitive in the market.

According to the t-test and ANOVA results for differences in the level of satisfaction based on respondent characteristics, there is a difference in satisfaction between male and female respondents. More specifically, the results suggest that female customers require higher service standards in the banking industry than their male counterparts. Customer age and experience showed no differences in the level of satisfaction.

Vietnamese commercial banks (VCBs) have developed banking services with many extra advantages, particularly for deposit services. This study examines the relationships between the factors in the SERVQUAL model and customer satisfaction with the use of deposit services of VCBs. The empirical analysis employed data from 150 customers who used deposit service of VCBs. The principle component method was used in the exploratory factor analysis. To test the hypotheses, a regression analysis was conducted. According to the results, all five factors (tangibility, assurance, responsiveness, reliability, and empathy) were positively related to customer satisfaction. However, reliability had only partial support. The t-test and ANOVA results indicate differences in the satisfaction level between male and female respondents. However, experience and age did not predict customer satisfaction. The implications of these results and the limitations of this study are discussed for potential avenues for future research. 
To minimize the distance between banks and customers, banks should increase the professional level of staff members providing services directly to customers. Such staff members should clearly understand and master their products as well as utility to ensure an appropriate level of their advisory capacity and ability to accommodate customers. In addition, they should have strong "soft" skills in the provision of services, including communication, negotiation, and sales skills.

This study is cross-sectional in nature, and therefore it is not possible to infer timeseries causality. In this regard, future research should consider a longitudinal design to examine the cause-and-effect relationship and analyze changes in variables over time.

\section{ACKNOWLEDGEMENTS}

This research was supported by the Daegu University Research Grant 2015.

\section{References}

[1] M. G. Angur, R. Nataraajan and J. S. Jahera, "Service quality in the banking industry; an assessment in the developing economy", International Journal of Bank Marketing, vol. 17, no. 3, (1999), pp. 116-123.

[2] D. Bachelet, "Measuring satisfaction; or the chain, the tree, and the nest, customer satisfaction research", Brooker, R.(ed), EMOSAR, (1995).

[3] R. N. Bolton and J. H. A. Drew, "Longitudinal analysis of the impact of service changes on customer attitudes", The Journal of Marketing, (1991), pp. 1-9.

[4] D. R. Cooper and P. S. Schindler, "Business Research Methods (11th ed.)", McGraw-Hill/Irwin, New York, (2011).

[5] P. B. Crosby, "Quality is free: The art of making quality certain”, McGraw-Hill, New York, (1979).

[6] R. L. Gorsuch, "Factor Analysis (2nd ed.)", Erlbaum, Hillsdale, NJ, (1983).

[7] C. Herington and S. Weaven, "Can banks improve customer relationships with high quality online services?”, Managing Service Quality, vol. 17, no. 4, (2007), pp. 404-427.

[8] R. Hinson, A. Mohammed and R. Mensah, "Determinants of Ghanaian bank service quality in a universal banking dispensation", Banks and Bank Systems, vol. 1, no. 1, ( 2006).

[9] A. K. Kashyap, R. Rajan and J. C. Stein, "Banks as liquidity providers: An explanation for the coexistence of lending and deposit-taking", NBER Working Paper Series, no. 6962, (1999).

[10] C. Lymperopoulos, I. E. Chaniotakis and M. Soureli, "The importance of service quality in bank selection for mortgage loans", Managing Service Quality, vol. 16, no. 4, (2006), pp. 365-379.

[11] R. C. MacCallum, K. F. Widaman, K. J. Preacher and S. Hong, "Sample size in factor analysis: The role of model error", Multivariate Behavioral Research, vol. 36, (2001), pp. 611-637.

[12] R. C. MacCallum, K. F. Widaman, S. Zhang and S. Hong, "Sample size in factor analysis", Psychological Methods, vol. 4, (1999), pp. 84-99.

[13] M. P. Moreau, S. E. Bruse, R. David-Rus, S. Buyske and L. M. Brzustowicz, "Altered microRNA expression profiles in postmortem brain samples from individuals with schizophrenia and bipolar disorder”, Biol. Psychiatry, vol. 69, (2011), pp. 188-193.

[14] T. V. Quyet, N. Q. Vinh and T. Chang, "Service Quality and Its Effects on Customer Satisfaction with Deposit Services in the Banking Industry", Advanced Science and Technology Letters, Business, vol. 102, (2015), pp. 18-23.

[15] F. F. Reichheld and W. Sasser, "Earl Zero defections: quality comes to services", Harvard business review, vol. 68, no. 5, (1990), pp. 105-111.

[16] C. A. Samli and C. J. Frohlich, "Service: the competitive edge in banking", Journal Services Marketing, vol. 1, (1992), pp. 15-22.

[17] E. Tsoukatos and E. Mastrojianni, "Key determinants of service quality in retail banking", EuroMed Journal of Business, vol. 5, no. 1, (2010), pp. 85-100.

[18] Y. Wang, H. Lo and Y. V. Hui, "The antecedents of service quality and product quality and their influences on bank reputation: evidence from banking industry in China", Managing Service Quality, vol. 13, no. 1, (2003), pp. 72-83.

[19] R. D. Zell and T. G. Bradley, "The PIMS principles: Linking strategy to performance", Free Press, New York, (1987). 
International Journal of $u-$ and e- Service, Science and Technology Vol.8, No. 8 (2015) 